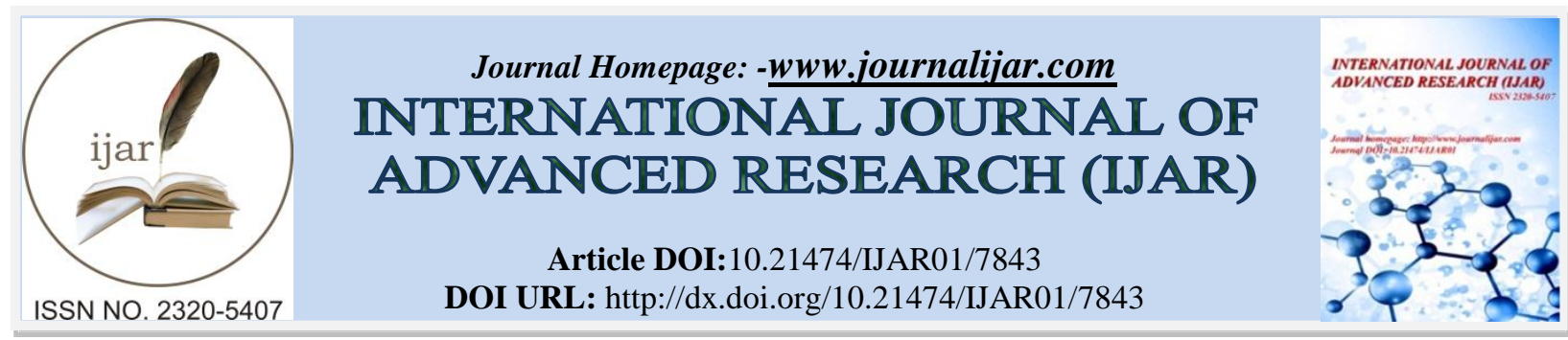

RESEARCH ARTICLE

\title{
THE EFFECT OF FISCAL DECENTRALIZATION ON ECONOMIC GROWTH AND ECONOMIC DISPARITY IN MALUKU PROVINCE.
}

Rein Joseph Wekan, Madris and Harryanto.

1. Magister of Local Government Finance, Faculty of Economics and Business, Hasanuddin University, Indonesia.

2. Faculty of Economics and Business, Hasanuddin University, Indonesia.

\section{Manuscript Info}

Manuscript History

Received: 8 August 2018

Final Accepted: 10 September 2018

Published: October 2018

\section{Keywords:-}

fiscal decentralization, economic growth, economic disparity, Maluku Province..

\section{Abstract}

The success of development can be achieved through increasing the economic growth that will then synergize with the improvement of the society welfare as the main goal of a country. Through the regional autonomy policy implemented effectively by the government as of $1^{\text {st }}$ January 2001 and to be recognized as a very democratic policy because the government system in Indonesia adhered to the principles of decentralization, deconcentration and co-administration duty which implicated on equitable, fair and balanced development growth, it is expected to provide positive impact on the economic growth in the autonomous region.This study aimed to analyze the effect of fiscal decentralization on economic disparity among the regions in Maluku Province either directly or through the economic growth.The type of the data used is pooled data which is as combination of time series data that is 2010 to 2016 and cross section data was eleven regency municipality, using by regression pooled data analysis with the help of Eviews 9 software. The results of the study shown that the fiscal decentralization did not affect the economic disparity. The Economic growth has a negative and significant effect to economic disparity among the region. The Fiscal decentralization has a significant effect on economic disparities through economic growth, due to the increasing of fiscal decentralization raised the economic growth and pressed economic disparities among the regions.

Copy Right, IJAR, 2018,. All rights reserved.

\section{Introduction:-}

The regional autonomy imposed by the government as of $1^{\text {st }}$ January 2001 gave an unhampered to local government could manage its region in order to achieve the society welfare. The local autonomy and the fiscal decentralization were the government system policy that give authority to the region in increasing public service to the society.The authority allotment from government to local governments of financial sector be based on the principle of money should follow function (Bahl, 1999).

The decentralization implementing in Indonesia for 8 years recently shown a fact, that most of the regions were not ready yet to implement decentralization system in the form of local autonomy, and this was caused the region was not optimized yet the role of PAD (Locally-Generated Revenue) even more dominant in fund transfered in APBD 
(Regional Income and Expenditure Budget) that always increased, and there was any depending on central government.

The decision of fiscal decentralization needed economy growth increasing in the region. Based on the Tiebout Model theory as a basic of fiscal decentralization concept whereas with authority delegation would increasing the local capability serving a better and efficient public goods demand. The fundamental causing of the capacity increasing was the local goverment was considered known much about demand and the local society character, so the programs from goverment will be more effective to run, and of course by public budgeting side could be found the efficiency concept because of the efficient and the effectiveness.

The fiscal decentralization issue as a way to support the economic growth has been studies by many experts such as Oates (1993), Bird (1993) and Gramlich (1993). They stated that, by implementing the regional autonomy was hopped the service of public getting effective and efficient so would forced the economic growth. This was confirmed by Prud'homme (1995) research in United States, Phillips and Woller (1997) for development country's cases, Zang and Zao (2001) research in India. They concluded that, there was a positive and significant influenced of fiscal decentralization on economic growth. In Indonesia, this study results was consistent with the research doing by Wibowo (2008), Sasana (2009), and Priyarsono (2010).

However, the fiscal decentralization will also be negative impacted to economic growth, then will cause a macroeconomic instability and later hampered the economic growth because the fiscal decentralization is going to reduce the government spending and the taxes used of government carrying out the stability function (Martinez and $\mathrm{McNab}, 2001)$.

In other hand, the fiscal decentralization could increased people's welfare, but in other side, the decentralization could be also had a negative consequency such as inequality among the regions, the instability of macroeconomic condition and so on. This was inforced by the research of Suryanto, et al (2005) found that the fiscal decentralization was not useful much for improving the society welfare because there was a gap between planning and demand of society in the region.

Widhiyanto (2008) argues that based on the research yield of fiscal decentralization in Indonesia was found that the fiscal decentralization not only could be influenced on economic growth but also could reduced the regional income inequality per capita. Also confirmed by the research results of Akai and Sakai (2005) stated that, fiscal decentralization was a tool used in increasing the efficiency of public sector and reducing desparity inter the regions. This was contrary with the study result doing by in other developing country that shown the fiscal decentralization be influnced on economic growth but could not reduce the income disparity. Several researches found that the fiscal decentralization has not been able overcome the economic disparity among the regions yet (Apriesa, 2013; Rochana, 2013; Dartanto and Brodjonegoro, 2004; Brodjonegoro, 2001; and LPEM FE-UI, 2001).

Patta (2012) stated according to his study result that the economic disparity among the regions had a negative effect with Human Development Index (HDI) as society welfare indicator. This meant, when the economic disparity among the regions getting lower caused a high welfare of society. Efriza (2014) and Apriesa (2013) expressed the study result about the influence of economic growth to the economic disparity inter-regions shown any negative relationship of economic growth and economic disparity among the regions. Meant that, if the economic growth getting higher it was impacted on the getting lower of the economic disparity inter-regions also affected a higher welfare level of society. This study result was accoured to Arthur Lewis Theory who stated that the economic growth was uncompleted process and was not balanced. So, in the growth process would arised a negative impact was the income disparity. In the beginning of the economic growth there was not completely development distributing in all regions, but at certain level whereas the dispatity income later became a regional inequality atep by step will getting decrease (Apriesa, 2013).

Based on data publication from Central Statistic Agency (BPS) shown that the economic growth data of regency/municipality from 2011 to 2016 shown a fluctuating condition but tended decline on the last year (West Southeast Maluku regency, Southeast Maluku regency, East Seram regency, Ambon municipality, and Tual town), and tended to increase in the last year (Central Maluku regency, Buru regency, Aru Islands regency, West Seram regency, South west Maluku regency, and South Buru regency). The average rate of economic growth for the last six years shown, that Southwest Maluku regency had the highest rate (6.69 percent) followed by Ambon municipality 
(6.62 percent), while the lowest rate was Buru regency (5.40 percent). If we compared with the growth rapid of province and national, then the average rate of economic growth of regency /municipality, the province and national had fluctuated and declined in the last year. In 2011, the economic growth average by regency/municapality (6.09 percent) was still below the province (6.34 percent) and for national (6.17 percent), while in 2016 were the same between regency/municipality and province (5.76 percent) and was higher than the national (5.02 percent) but still below of achievement level in 2011. This indicated that the level of the economic growth of regency/municipality was still low.

This was caused of fiscal decentralization proxy of regency/municipality in Maluku Province had fluctuated and tended to decline in 2016 if compared with the beginning of the year 2010. The fiscal decentralization proxy from 2010 to 2013 got the highest was East Seram regency were 20.05 percent, 17.64 percent, 18.44 percent and 15.25 percent. While from 2014 to 2016 the highest of fiscal decentralization proxy was Ambon municipality were 15.28 percent, 12.91 percent and 13.65 percent. The highest average proxy of fiscal decentralization achieved by East Seram regency about 14.60 percent, followed by Ambon municipality 13.67 percent, and the lowest was achieved by West Seram regency about 6.11 percent followed by Tual town about 6.91 percent. This shown that the local ability of the regions in running the local autonomy from year to year was getting lower and the level of dependence of central government was still very high, so the autonomy implementation did not run according to the expectations.

The economic disparity level among the regions shown that most of regency/municipality in Maluku Province were in the economic disparity level among the regions were low, and just few of them were in medium category. Averagely, the economic disparity rate among the regencies/municipality in Maluku Province dominantly in low category because the value of Williamson Index was still below 35 percent, and only Southwest Maluku regency with the index of 36 percent that in medium category (IW> 35 percent). The economic disparity rate inter the lowest region was Aru Islands regency (5.7 percent). This shown the condition that the fiscal decentralization and the growth of economy achieved had a good impact of disparity level by the regency/municipality.

Based on the inconsistency of the research yield on the relationship of fiscal decentralization on economic growth, then this research was done in order to know and to analyze the influece of fiscal decentralization on economic growth.

\section{Theoritical Review:- \\ Fiscal Decentralization}

Various studies on fiscal decentralization impact on economy and public service delivery can be explained in theoritical terms of fiscal federalism. This theory divided in two perspectives, that was traditional theory or first generation theories and new perspective theory or second generation theories. The first generation theories built by Hayek and Tiebout did not emphasized the capability of local governments for self-financing to finance expenditure. According to Musgrave and Oates in the second generation theory stressing that how important the revenue and expenditure assigment between government level. In government functional relationship associating with fiscal federalism, whereas the first generation theory supported the decentralization of the allocation function only by given the local government authority for expenditure assigment, while the secon generation theory supported the distribution of decentralization function by given an equal authority to the local government for revenue assignment including the expenditure assignment and these both theories were not influenced by government's stability function. So, the difference of both theories were on revenue transfer point of view. The connection between revenue and expanditure of local government throughout the limitation of central government would created incentive of local government in doing market orientation reformating.

According to Sasana (2009), the fiscal decentralization was a delegation of responsibilities and the division of power and authority for decision making in fiscal field including the revenue aspect (tax assignment) expenditure aspect (expenditure assignment). The fiscal decentralization associated with the local government's duty and function in preparing the society's goods/public service. In running the fiscal decentralization, with the principle (rules) money should follow function was one of the principle that should be paid attention and implemented. This means, that every handovered or delegating of government authority brough any consequenced on budget needed carrying out the authority. 
In general, the economy will get the growth naturaly from time to time by policy of fiscal decentralization hopefully the economic growth will be faster and bigger compared with naturally only because fiscal decentralization policy be aimed of the efficiency on public sector. The economic growth and the fiscal decentralization had a simultaneously relation because there were some causes whereas the growth seen as an object of fiscal decentralization that the efficiency of the resource allocating on public sector, then obviously the goal of government in adopting this policy was to support the increase of per capita income and the last that per capita income was an easier measure that could explained the economic condition when compared with other indicator (Apriesa, 2013).

\section{The Economic Growth}

The economic growth based on Kuznets definition stated that economic growth was a long-term increasing of one country capability providing more and more the economic goods type to its society; this ability grew according to technology advanced and the adjustment of the institution and the ideological needed. This definition had three components: First, the economic growth of one nation can be seen from the increasing continuously of good's stock. Second, the advanced technology was a factor in economic growth determining the ability growth degree in supplying various kind of goods to the society. Third, the widespreding technology using efficiently needed any adjustment in institutional and ideological field so the the innovation produced can be used properly Jhingan (1994).

Oates stated, that the economic progressing rate was the outcome of people's preference suitability with local government was created because the importance role of local government in regional autonomy. Theoritically, the fiscal decentralization will give the economic increasing because the local government had a closeness with their people and also had an information superiority than the central government, and the local government could gave a public service that needed in their area. The response given by the local government of society demanding was much faster because faced directly with the region/town population (Wibowo, 2008).

Other argument be based the fiscal decentralization was the competition appearing among the regions would increased the similarity point of view between the hope of society and the program running by its government (Davoodi and Zou, 1998). In accordance with, quoting Oates, Wibowo (2008) stated, that the fiscal decentralization had a potential given contribution in the form of the government efficiency increasing and the economic growth rate.

\section{The Economic Disparity}

The distribution of national income was reflected completely or just partial of development result of a country among its population. There were several kind of gaps that often blocked a society in effort gainning the prosperity such as : the regional disparity, the sectoral disparity, and the disparity of society income distributing (Basri, 1995). Various criteria or benchmarks to measure the completed distribution of income i.e: Lorenz Curve, Gini Index, World Bank criteria, and Williamson Index.

Many studies done about inequality among the regions. Kuznets (1954) was noted as one of the earliest researcher examining the gap. He studied it in various country by cross-sectional and found the an inverted $\mathrm{U}$ pattern. He concluded, that the average income per capicta of country's development in the bginning was still low also the disparity rate. When the average income got high, then followed by the disparity also. If the income rate getting higher, then the disparity will go down again.

Some approachings can be used to measure the regional inequality, one of them was the Williamson Index. This approach used to measure the dispersion of the income rate of regional per capita was relative to national income average.

\section{The Hypotheses}

Referring to various opinions above, then the research hypotheses was: (a) the decentralization had a significant influence to the economic disparity among the regions; (b) the economic growth had a significant effect on economic disparity among the regions; and (c) the decentralization had a significant effect on economic disparity among the regions via economic growth.

\section{Methodology:-}

The location of this research was the regency/municipality in Maluku Province. The province was a research site because from 2010 till 2016 this province did not get the regional expansion for its regencies/municipalities. In 
2010 the province chosen because the last year of the expansion before the expansion moratorium in 2009 and also can be seen the development after implementing the regional autonomy both for original regency and the expansion result of regency.

The type of the data using in this research was a secondary data, whereas the panel data in the form of time series data since 2010 to 2016 and the cross section data of eleven regencies/municipalities. The pooled data or the longitudinal data was a merge data between cross section data and time series data. The cross section data was the data that hed many analysis units collecting one at the time while the time series data was collected from time to time of one observation unit. The panel data was used to do an empirical analysis that can not be done using by cross section data or time series data only.

According to the nature and the characteristic of the research, this study was a quantitative. The analysis using in this research was econometric model reflected the result and the discussion expressed in numerical and to support the analysing using with software Eviews 9 to ease the calculating or estimating the data in this study. The analysis done using by variable thought influenced the economic growth was fiscal decentralization variable with panel data regression method. The coefficient calculation process was approached through regression analysis with standardized regression.

The operational definition variables of this research was:

\section{The Fiscal Decentralization}

In this research, the fiscal decentralization variable was proxied with the ratio between Regional Original Revenue (PAD) plus Tax Result Shared and Non-Tax (DBH) with total expenditure realization of regency/municipality government. This variable used refered to Mahi (2000). The fiscal decentralization in this research was explained in percent unit.

\section{The Economic Growth}

The economic growth was defined as GRDP increased regardless whether the increase was greater or less from the population growth level or the economic structure changing was hapened or not. The GRDP used was be based on constant price of 2010. The economic growth in this research was measured by with the ratio between GRDP in the year t minus GRDP in the year t-1 GRDP in the year t-1 that expressed in percent unit.

\section{The Economic Disparity}

The economic disparity among the regions was an economic disparity amongs the regions (regency/municipality) in Maluku Province, that measured by comparing per capita income rate depression and the amount of local population of regency/municipality of province income rate and proxied with Williamson Index value of each regency/municipality in percent unit.

\section{Result And Discussion:- The Analysis Result}

Based on panel data regression analyzing seen, that the fiscal decentralizationa positively influenced but did not significant to economic disparity among the regions with the probability level arround 0.2998 >0.05. While the economic growth variable was negatively influenced and was significant to economic disparity among the regions with the probability rate about $0.0046<0.05$, with the influenced coefficient about 0.397801 . This was shown, that at a rate of 1 percent increasing of economic growth could reduced the economic disparitiy among the region around 0.397801. The r-squared value shown, that abot 95.95 percent of fiscal decentralization variable and economic growth variable could explained the economic disparity among the regions and arround 4.05 percent was explained by other variable out of this model.

On the other hand, the fiscal decentralization had a positive influenced and significant to the economic growth with the probability rate about $0.000<0.05$, with the influenced coefficient value was 0.101540 . This shown, that on at the rate of increase 1 percent fiscal decentralization could increased the economic growth about 0.101540. The rsquared value shown that around 27.40 percent fiscal decentralization variable could explained the economic growth variable and around 72.60 percent was explained by variable out of this model. 


\section{Discussion:-}

The research yield shown, that decentralization was not influenced to economic disparity among the regions. This finding was lined with the research done by Apriesa (2013) and Rosdyana (2015), who found that the fiscal decentralization be influenced was not significant to the economic disparity among the regions that caused the eficiency and effectivity of government in public good providing by fiscal decentralization was not optimum yet. If was not significant meant that the fiscal decentralization was not appropriated enough using predicted the economic disparity among the regions. This finding was contracted with the research yield done by Akai and Sakata (2005), Sasana (2009) and Kundhani (2015) explained that the fiscal decentralization had a negative influenced and significant to economic disparity among the regions.

The finding result was disputed cause by several factors like the concentration of region economic activity wa still dominant centered in the capital of regeny/municipalty, the low investment that caused low productivty rate because no economic activities productively, low employment opportunity because the society focused on to be a civil worker rather than opening new business alhough the natural resource was great, was not optimalizing yet the natural resources also caused the economic disparity among the regions, besides the demographic factor and trading swiftness could be the problem that could not ovrcame yet because the vast of the sea area was dominant than the land area (Tambunan, 2011). This condition shown, that the backwash effects more dominant than the spread effects that caused imbalanced due to the economic disparity among the regions (Myrdal, 1957).

The economic growth had a negative influenced to economic disparity among the regions shown that when the economic growth getting higher will caused the the economic disparity among the regions getting lower. The finding result was consistant with Kuznets's theory concluded, that the growth and the disparity had a very strong correlation, at the beginning of the economic growth will caused on increasing disparity because the income was not distributed completely, but in he next step the completing will achieve and the disprity rate will go down. Kuznets described the increase and the decrease pattern with the inverted U method who created after studied the disparity in various countries. This finding result was not in line with the research done by Sasana (2009) and Rama et al (2014) concluded, that the economic growth ha a negative effect to economic disparity among the the regions.

The economic growth could mediated the influence of fiscal decentralization on the economic disparity among the regions. This was caused the fiscal decentralization had a significant influenced to the economic growth and the economic growth had a significant influenced to the economic disparity among the regions with the influence coefficient value about 0.0403 .

\section{Conclusion:-}

Based on the research result and the discussion, it can be concluded that, the fiscal decentralization did not affect the economic disprty among the regions directly. The fiscal decentralization had influence on economic disparitiy among the regions and could reduced it if the economic growth could be increased.

Thus, be suggested the local government to increase the fiscal decentralization proxy to be addressed in increasing the economic growth. Instead of, than the local government could created the investment climate and created the employment chance on productivity sector so could supported the society income increasing that estuaried on increasing the economic growth . by increasing the economic growth will press the disparity rate among the regions. Known that Maluku as a province that be as archipelago basis so the economic disparity among the regions will be felt the impact compared with the region that based on land. 


\section{References:-}

1. Akai, Nabuo dan Sakata, Masayo, 2005. Fiscal Decentralization, Comittment and Regional Inequality: Evience from State-Level Cross-sectional Data forthe United States. CIRJE-F-315.

2. Apriesa, Lintantia Fajar dan Miyasto, 2013. Pengaruh Desentralisasi Fiskal Terhadap Pertumbuhan Ekonomi Daerah dan Ketimpangan Pendapatan (studi Kasus: Kabupaten/ Kota di Jawa Tengah). Jurnal Ekonomi UNDIP, Vol. 2, Nomor 1.

3. Bahl, Roy, 1999. Implementation Rules for Fiscal Decentralization, A Paper Prepared for International Seminar on Land Policy and Economic Development, Taiwan: Land Reform Training Institute, hlm. 4-28.

4. Bird, R. M.,1993. Threading the Fiscal Labyrinth: Some Issues in Fiscal Decentralization. National Tax Journal, 46(3), hal. 207-227.

5. Davoodi, H., Xie, D., dan Zou, H., 1998. Fiscal Decentralization and Economic Growth in the United States, Journal of Urban Economics XLV:228-39.

6. Fadjar A. D dan Britany Alasen Sembirin, 2007. Efektifitas Faktor Input dan Ketimpangan Pendapatan Daerah di Indonesia Setelah Desentralisasi Fiskal, Pusat Penelitian Ekonomi Wibiz.

7. Gramlich, E., 1993. A Policy Maker's Guide to Fiscal Decentralization. National Tax Journal, XLVI, hal. 229235.

8. Iimi, Atsushi, 2005. Decentralization and Economic Growth Revisited: an Empirical Note, Journal of Urban economics 57.

9. Jhingan, ML, 1994. Ekonomi Pembangunan dan Perencanaan, Jakarta: PT Raja Grafindo Persada.

10. Martinez, V. J. M., and McNab, R., 2001. Fiscal Decentralization, Economic Growth, and Democratic Governance, Working Paper.

11. Patta, Deviyanti, 2012. Analisis Faktor-Faktor yang Mempengaruhi Indeks Pembangunan Manusia di Sulawesi Selatan Periode 2001-2010. FEB Universitas Hasanuddin, Makassar.

12. Phillips, K. L., \& Woller, G., 1997. Does Fiscal Decentralization Lead to Economic Growth?. Working Paper.

13. Priyarsono, DS. dkk., 2010. Desentralisasi Fiskal, Tax Effort, dan Pertumbuhan Ekonomi: Studi Empirik Kabupaten/Kota di Indonesia 2001-2008,Jurnal Ekonomi Pembangunan Indonesia, Vol. XI, No. 1, Juli 2010:21-34.

14. Prud'Homme, Remy, (1995). On the Danger of Decentralization, Washington D.C., The World Bank, Policy Research Working Paper, 1252.

15. Rosdyana et al., 2015. Desentralisasi Fiskal Terhadap Pertumbuhan Ekonomi Regional dan Ketimpangan Pendapatan di Pulau Jawa 2009-2013. Jurnal Psikologi, Ekonomi, Sastra, Arsitektur dan Sipil Universitas Gunadharma, Volume 6, p. 123-132.

16. Sasana, Hadi, 2009. Analisis Dampak Pertumbuhan Ekonomi, Kesenjangan Antar Daerah dan Tenaga Kerja Terserap Terhadap Kesejahteraan di Kabupaten/Kota Provinsi Jawa Tengah Dalam Era Desentralisasi Fiskal, Jurnal Terakreditasi, Jurnal Bisnis dan Ekonomi (JBE), Vol. 16, No. 1, Maret 2009: 50-59.

17. Oates, Wallace E., 1993. Fiscal Decentralization and Economic Development, National Tax Journal, Vol. 46, No. 2, Juni 1993:237-243.

18. Wibowo, Puji, 2008. Mencermati Dampak Desentralisasi Fiskal terhadap Pertumbuhan Ekonomi Daerah,Jurnal Keuangan Publik, Vol. 5, No. 1, Oktober 2008:55-83.

19. Zhang, T., dan Zou, H., 2001. The Growth Impact of Intersectoral and Intergovermental Allocation of Public Expenditure: With Application in China and India. China Economics. 